\title{
ISKOLA, KARRIER ÉS A VALÓSÁG
}

\author{
DEÁK DOROTTYA
}

ELTE TáTK Szociálpolitika Doktori Program

\begin{abstract}
Barry Down, John Smyth \& Janean Robinson: Rethinking School-to-work Transitions in Australia: Young People Have Something to Say. Cham, 2018. Springer. xv + 174 p. ISBN 978-3-319-72269-6 (eBook)
\end{abstract}

A felnőtté válás folyamata, amikor a fiatalok az iskolai védett környezetből kikerülve a munkaerőpiac hatalmas világával szembesülnek, minden fiatal életében természetes krízisként jelenik meg. Számos olyan környezeti hatás is éri őket ebben az időszakban, amely döntően meghatározhatja karrierlehetőségeiket, mint pl. az adott ország gazdasági helyzete, az oktatási rendszer minősége, a társadalom felépítése vagy kulturális értékei stb.

$\mathrm{A} z$ iskolarendszerből a munkaerőpiacra való átmenet nehézségeiről szól Barry Down, John Smyth és Janean Robinson Retbinking School-to-work Transitions in Australia: Young People Have Something to Say címü, 2018-as könyve, mely fiatalokkal készített interjúk elemzése mentén kívánja bemutatni az ausztrál fiatalok tanulmányi lehetőségeit szakmai karrierjük építéséhez és a munka világába való belépéshez. Bár a kötet kiemelten foglalkozik a neoliberalizmus ideológiáját követő ausztrál oktatási rendszerrel és annak gazdasági sajátosságaival, a felvetett kérdések és problémák más szemléletek mentén müködő oktatási rendszerek vizsgálatában is megállnák a helyüket.

A könyv három jól elkülönülő részből, ezen belül kilenc fejezetből áll. Az első két fejezet elméleti alapozást nyújt az olvasó számára a kutatás céljáról és fontosságáról, illetve a kutatásban felmerülő problémák társadalmi, gazdasági, kulturális és politikai hátteréről, továbbá részletesen ismerteti a kutatás során használt kritikai etnográfiai módszer sajátosságait, a kutatás és az interjúk felvételének körülményeit.

A szerzők egyik alapgondolata, hogy az oktatási rendszert azok nélkül építik fel és mủködtetik, akikről igazán szólnia kéne, vagyis a diákok nélkül. Pozitív változás, amin a szerzők egy, a tanulók igényeire épülő, gazdasági- és munkaerőpiaci anomáliákra reagáló oktatási reformot értenek, csak akkor valósulhat meg, ha a fiatalokat megkérdezik a valós szükségleteikről. A 2011 és 2014 között lezajló kutatás során harminckét 14 és 17 év közötti Nyugat-Ausztráliában élő és tanuló fiatallal készítettek interjút három fázisban. $\mathrm{A} z$ interjúalanyok többsége hátrányos helyzetű, munkás szülőktől származó, eltérő etnikumú, állami iskolában, magániskolában vagy TAFE-képzésben tanuló diák. ${ }^{1} \mathrm{Az}$

\footnotetext{
A TAFE (Technical and Further Education) Ausztrália egyik legelterjedtebb oktatási típusa. A TAFE-intézményekben többszintű végzettséget lehet szerezni (Certificate I-től az Advanced Diplomáig). Szintektől függően eltérő ideig tartanak a képzések. Sok esetben az egyetemek beszámítják a TAFE-iskolákban végzett tanulmányokat a képzési idejükbe.
} 
első fázis során a kutatók olyan kérdésekre kerestek választ, hogy hogyan pozícionálják magukat a fiatalok a társadalomban, milyen erőforrásokkal rendelkeznek, milyen jövőbeli terveik vannak, milyen családi háttérrel rendelkeznek. Egy év elteltével a második fázisban a cél a fiatalok fejlödésének nyomon követése volt. Az ebben a körben felvett interjúk során a fókusz az életüket és döntéshozatalukat befolyásoló tényezőkre összpontosult. A harmadik fázis alkalmával a fiatalok visszatekintettek az első interjú során elmesélt karrierterveikre és az azóta eltelt folyamatra.

$\mathrm{A} z$ interjúkból a kutatók portrékat készítettek, segítségül a könnyebb átláthatósághoz, felmérve, hogy milyen azonos szükségletek merültek fel az interjúalanyok történeteiben. A portrék alapján megállapítottak 16 pedagógiai és társadalmi feltételt, amely meghatározó a fiatalok munkavállalásában és karrierépítésében. E 16 feltétel alapján hat nagyobb területet jelöltek ki, melyek külön fejezetként, interjúrészletekkel szemléltetve jelennek meg a tanulmányban. A kutatás során felvett interjúk bemutatása e témák szerint rendezve adja a tanulmány második és legnagyobb részét.

A harmadik fejezetben (Growing $U_{p}$ in Neoliberal Times) a kutatók arra keresik a választ, hogy a globális világgazdaság változásai milyen mértékben befolyásolják a fiatalok munkaszerzési lehetőségeit. A rendszert fenntartó hatalom a magas fiatalkori munkanélküliségi ráta okait nem a mögöttes strukturális és intézményi rendszerek hibáiban keresi, hanem az egyéneket (a rendszer áldozatait) hibáztatja. Ezzel szemben a valóság az, hogy a globális gazdaság kevésbé képzett, kreatív és elemző ismeretekkel foglalkozó munkavállalót igényel, és egyre több alkalmi, részmunkaidős, marginális munkahelyet teremt, melyek nem kapcsolódnak képzési vagy karrierútvonalakhoz. A tudásalapú gazdaság retorikája és a magasan képzett, csúcstechnológiájú és jól fizetett munkahelyek ígérete egyre nagyobb számú fiatal számára már csak illúziónak bizonyul. A 2008-as pénzügyi világválság még a ma élő fiatalok munkába állási lehetőségeire is hatással van. A teljes munkaidős állások gyorsabb ütemben szünnek meg, mint ahogyan megjelennek a piacon. A hatalmi elit által működtetett iskolai rendszer retorikája az, hogy a diákok legyenek rugalmasak, ne élethosszig tartó és önmegvalósító munkát keressenek, hanem fogadjanak el bármilyen alacsony iskolázottságot vagy képzettséget nem igénylő, alulfizetett és monoton (többnyire részidős vagy alkalmi, szezonális) munkát, vagyis élteti azt a gondolatot, hogy a fiatalok a „kezükkel” dolgozzanak, ne az „eszükkel”. Míg az ausztrál társadalom az esélyegyenlőséget hirdeti, a kutatás eredményeiből jól kirajzolódik, hogy a valóság messze eltér az egalitárius társadalom fogalmától. A képzésekben mesterségesen szét lett választva a szakképzésben ragadás és a diplomaszerzés felé vezető út, aminek célja a kapitalizmus érdekeinek jobb kiszolgálása, ezzel csökkentve a társadalmon belüli és intergenerációs mobilitás lehetőségét. $\mathrm{A} z$ oktatási rendszer ezáltal növeli és mélyíti a nemi, etnikai származáson és társadalmi osztályokon alapuló egyenlőtlenségeket.

A negyedik fejezet (Retbinking Class and Deficit Thinking) az "elfelejtett középnek”, „dolgozó szegénynek” vagy „elfeledett embereknek" nevezett munkásosztály gyermekeinek lehetőségeit vizsgálja. $\mathrm{A} z$,elfelejtett közép”-hez azok tartoznak, akiknek a gazdasági válságot követően bizonytalanná vált a foglalkoztatásuk, akik elvesztették a munkahelyüket, jelentős jövedelemcsökkenést tapasztaltak, egyre nagyobb adóterheik vannak, kevés megtakarítással rendelkeznek, és gyermekeiket nem tudják támogatni a magasabbra emelkedésben. Az interjúrészletek bemutatják, 
hogy az oktatási intézményekben a szakmai tudás mellett a diákok nem jutnak olyan képességekhez, melyek ahhoz kellenének, hogy a munkaerőpiacon boldogulni tudjanak.

Az ötödik fejezetben (Transitioning to Adulthood) a kutatók az iskolák felelősségére világítanak rá. $\mathrm{Az}$ interjúkból kiderül, hogy a fiatalok szerint az iskolák túl szüken értelmezik kapun belüli munkájukat, pedig nekik olyan kompetenciák megszerzésére is szükségük lenne, melyek az iskola utáni életre készítik fel őket, akár a továbbtanulás terén, akár a munka világában. A diákok nem neoliberális szemléletű, szabványosított, tesztíráson, elszámoltathatóságon és előírt tanterv alapján működő közoktatást szeretnének, hanem olyat, ami képes megfelelni az érdekeiknek és érdeklődési körüknek. Az interjúk egyik legfontosabb üzenete $a z$, hogy az iskola és a benne zajló események nagyrészt irrelevánsak a fiatalok élete, jövőjük elérése szempontjából. Az oktatás további problémája, hogy a hátrányos helyzetü térségekben gyenge a munkaerőpiac és magas a munkanélküliség, rossz a közlekedési infrastruktúra, ami mélyíti a társadalmi egyenlőtlenséget és társadalmi kirekesztettséget, ezzel akadályozva a fiatalok tanulmányi fejlődésének lehetőségét.

A hatodik fejezet (Reinvigorating Pedagogy), ahogy arra a címe is utal, a pedagógia megújulásával foglalkozik. $\mathrm{Az}$ interjúkból egy igen negatív kép rajzolódik ki az iskoláról: börtönökre vagy blokkos ütemtervvel működő gyárakra emlékeztet, ahol továbbra is frontális oktatás folyik. A szerzők úgy vélik, hogy a pedagógia revitalizációjával előtérbe kell helyezni a fiatalok szükségleteit és érdekeit, a tanárok és diákok között bizalmon és tiszteleten alapuló kapcsolat kiépítésével. A diákok, különösen a marginalizált tanulók, gyakran nincsenek tisztában azzal, hogy az iskolában szerzett ismereteik mennyi- re hasznosak, kapcsolódnak-e egyáltalán személyes érdekeikhez, igényeikhez, elvárásaikhoz és képességeikhez. Nincs eszközük arra, hogy utánanézzenek, mihez tudnának kezdeni a tudásukkal, milyen lehetőségük van a továbbtanulásra vagy a munka világában elhelyezkedni, emiatt kiemelkedő a pedagógusok szerepe, hogy a tananyag átadásán túl segítsék a fiatalokat a jövőképük kialakításában és lehetőségeik megismerésében.

$\mathrm{A} z$ iskolából a munka világába átmenet témájának vizsgálata során elengedhetetlen azon csoportok nehézségeinek feltárása, akik valamilyen oknál fogva érzékenyebbek a rendszer müködése iránt, és pluszsegítséget igényelnek tanulmányuk és munkakeresésük idején. A hetedik fejezet (Giving All Students a Fair Go) a fogyatékossággal élő és az „elveszett, zavart és kallódó" fiatalok helyzetét mutatja be. A "társadalmilag igazságos iskola” gondolatára támaszkodva és a fejezetben bemutatott interjúk alapján azt fejtegeti, hogy a leginkább hátrányos helyzetben lévők érdekében milyen módon kellene átalakítani az oktatáspolitikát, és milyen gyakorlatokat kellene bevezetni annak érdekében, hogy ezek a diákok is érvényesülhessenek iskolai éveik alatt és után egyaránt. A közhiedelemmel ellentétben az OECD-adatok nem egy egalitárius társadalom képét mutatják. Ausztráliában a fogyatékos személyek 45\%-a él szegénységben vagy annak közelében, ami több mint kétszerese az OECD-országok átlagának. A fogyatékossággal élők foglalkoztatási arányát tekintve a 29 OECD-ország közül Ausztrália a 21 .

A második rész utolsó fejezete (Understanding Young Lives) a diákok eltérő szociális helyzetéből adódó különbségekre hívja fel a figyelmet. A kedvezőtlen személyes és családi körülményekkel küzdő fiatalok olyan kihívásokkal szembesülnek tanulmányaik alatt, amilyenekkel 
magasabb státuszú családból jövő társaik egyáltalán nem találkoznak. A hátrányos helyzetből jövő hallgatóknak gyakran dolgozniuk kell iskola mellett részmunkaidőben, hogy támogassák családjukat, esetleg segítséget nyújtsanak rossz egészségi állapotú vagy szerfüggő, alkoholproblémákkal küzdő rokonuknak. A fejezet arra keresi a választ, hogy az iskola miként tudna támogató és biztonságos légkört teremteni az ilyen diákok számára. A neoliberális oktatási rendszerben, ahol az eredmények számítanak, ahol a gyermekeket számszerüsített teljesítményük alapján rangsorolják, és személyesen őket teszik felelőssé a rosszabb teljesítmény miatt, nem veszik figyelembe a diákok eltérő családi helyzetét vagy nemzetiségét, vagy olyan megkerülhetetlen okokat, mint a testi vagy mentális betegségek, jóllehet, ezek hatással vannak a tanulásra és iskolai teljesítményre. Vagyis egy olyan humanizáltabb pedagógiára lenne szükség, amely figyelembe veszi a diákok hátterét, kultúráját és élettapasztalatait, ezzel elősegítve, hogy ők is olyan lehetőségeket kapjanak, mint azok a társaik, akik stabil egzisztenciájú családban élnek.

A kötet harmadik részében a szerzők a kutatás eredményeinek konklúzióját ismertetik. A fiatalok történetei alapján egyre szélesedő szakadék képe rajzolódik ki az oktatási intézmények müködése és a fiatalok igényei között. Szerintük szükség van emiatt az oktatási rendszer újragondolására, hogy az iskolák, a szakmai tudás átadása mellett támogassák a fiatalokat a munka gyors ütemben változó világában való elhelyezkedésben. Általános vita folyik arról, hogy az oktatás a munkaerőpiac szempontjából releváns képességekkel és tudással ruházza-e fel a diákokat. Ilyen jellegü viták gazdasági és társadalmi válságok idején különösen előjönnek (pl. az 1930-as évek visszaesésekor, az 1970-es évek recessziójánál, vagy napjainkban a 2008-as globális pénzügyi válság után). Bár a magasabb szintű szakmai és egyetemi képzésekkel - a korábbi gyakorlatokkal ellentétben - igyekeznek az alacsonyabb társadalmi státuszú szintek felé nyitni, továbbra is fennáll a társadalmi egyenlőtlenség reprodukciójának mintája. A szerzők ugyan nyitva hagyják a probléma megoldását, de egy sor kulcsfontosságú kérdést tesznek fel az iskolai rendszert müködtető szereplők számára a politika és a gyakorlat újragondolásának provokációjaként.

Down, Smyth és Robinson kötetének címe az iskola és munka közötti átmenet vizsgálatát ígéri az ausztrál iskolákban, és ennek eleget is tesz. Bár az alapul szolgáló kutatás kiemelten az ausztrál oktatási rendszer felépítésére fókuszált, könyvükben a szerzők olyan alapelveket vetnek fel, amelyeket nemcsak az ausztrál iskolák működésébe lehetne beépíteni. Emellett számos olyan problémát emelnek ki, illetve általános jellemzőket írnak le, amelyek a szabad piac és a globalizáció térhódításával a tudásalapú gazdaság retorikájára épülő egyéb nemzetállamok oktatáspolitikájában is megjelennek.

A cikk a Creative Commons Attribution 4.0 International License (https://creativecommons.org/licenses/ by/4.0/) feltételei szerint publikált Open Access közlemény, melynek szellemében a cikk bármilyen médiumban szabadon felhasználható, megosztható és újraközölhető, feltéve, hogy az eredeti szerző és a közlés helye, illetve a CC License linkje és az esetlegesen végrehajtott módosítások feltüntetésre kerülnek. (SID_1) 